\title{
ARTICLE OPEN \\ In situ nuclear-glass corrosion under geological repository conditions
}

\author{
Mathieu Debure (D) $^{1 *}$, Yannick Linard $\mathbb{D}^{2}$, Christelle Martin ${ }^{2}$ and Francis Claret (iD)
}

Silicate glasses are durable materials but laboratory experiments reveal that elements that derive from their environment may induce high corrosion rates and reduce their capacity to confine high-level radioactive waste. This study investigates nuclear-glass corrosion in geological media using an in situ diffusion experiment and multi-component diffusion modelling. The model highlights that the $\mathrm{pH}$ imposed by the Callovo-Oxfordian (COx) claystone host rock supports secondary-phase precipitation and increases glass corrosion compared with pure water. Elements from the COx rock (mainly Mg and Fe) form secondary phases with Si provided by the glass, which delay the establishment of a passivating interface. The presence of elements (Mg and Fe) that sustain glass alteration does not prevent a significant decrease in the glass-alteration rate, mainly due to the limited species transport that drives system reactivity. These improvements in the understanding of glass corrosion in its environment provide further insights for predictive modelling over larger timescales and space.

npj Materials Degradation (2019)3:38; https://doi.org/10.1038/s41529-019-0100-7

\section{INTRODUCTION}

Glass corrosion that occurs when in contact with aqueous media has been studied in many fields, such as biogeochemical weathering of volcanic glasses in seawater, ${ }^{1,2} \mathrm{CO}_{2}$ sequestration, ${ }^{3}$ historical and archaeological artefact conservation, ${ }^{4,5}$ and industrial applications. ${ }^{6,7}$ The chemical durability of silicate glasses makes them suitable for high-level radioactive waste (HLW) containment that arises from dismantling operations or spentfuel recycling processes. In HLW disposal facilities, the different phases, i.e., construction and operation procedures that introduce radioactive waste, induce chemical gradients across the disposal components. ${ }^{8,9}$ Due to these chemical gradients, perturbations, such as changes in the $\mathrm{pH}$ or redox conditions, may alter the performance of silicate glasses over time. ${ }^{10}$ Understanding the mechanisms that support aqueous corrosion in glasses relies on an iterative approach that begins with simplified systems [i.e., glass in contact with pure water, groundwater, or simple minerals comparable with several environmental materials present in repository conditions (corrosion products, mineral phases, and similar factors) $]^{11-16}$ and moves toward more realistic disposal conditions. The spatial and temporal scales of interest in an HLW disposal facility are beyond the scope of laboratory experiments and require the development of multi-component reactivetransport models for long-term modelling predictions.

Numerous studies have focused on laboratory experiments to understand the key processes that occur during glass corrosion (e.g., water diffusion, ion exchange, hydrolysis, condensation, and precipitation reactions), ${ }^{9,17}$ as well as how to obtain host-rock conditions as accurately as possible. ${ }^{13,14}$ However, comparisons between laboratory data and field measurements may reveal discrepancies. Therefore, field data are necessary to validate our understanding of the key processes and long-term prediction of glass behaviour in repository conditions. ${ }^{18,19}$ For instance, glasscorrosion products are composed of an amorphous layer (or gel) and secondary phases, whose formation depends on environmental conditions (i.e., the temperature, $\mathrm{pH}$, redox, element saturation, groundwater, glass-clay ratio, and transport parameters). ${ }^{15,20-28}$

In this study, we investigate glass corrosion in the Meuse/ Haute-Marne Underground Research Laboratory (URL) operated by Andra using a nine-year in situ experiment involving SON68 glass, ${ }^{15}$ which is an inactive surrogate of the French R7T7 highlevel vitrified waste, and the Callovo-Oxfordian (COx) claystone rock that occurs in France as the host rock in the deep geological disposal project known as Cigéo. ${ }^{29}$ The reactive-transport modelling of this unique in situ experiment is a step forward toward a better understanding of the processes that induce glass corrosion in geological media by corroborating the mechanisms highlighted in the laboratory with the field results.

\section{RESULTS AND DISCUSSION}

We analysed in situ radioactive vitrified waste corrosion under geological disposal conditions through the diffusion of both synthetic and in situ COx porewater using a cylinder filled with glass powder, machined COx claystone blocks, and stainless-steel sintered filters in contact with the pristine COx formation (detailed in the "Methods" and Supplementary Fig. 1). The mean temperature of the experiment was $23^{\circ} \mathrm{C}$ and all data measured at each sampling are available in Supplementary Table 1. A 1-D radial model that accounts for both the in situ test interval and COx formation was used to represent the experimental geometry (Fig. 1a). The initial inner boundary condition was fixed by the synthetic COx porewater, whereas the initial outer boundary condition was fixed by the pristine COx porewater (Supplementary Fig. 2). A stepwise modelling approach was used. The diffusion coefficient of the non-reactive species (deuterium, $\mathrm{Br}^{-}$and $\mathrm{I}^{-}$) was first modelled to determine the transport parameters using a multi-component diffusion model (Fig. 1c). Then, we investigated glass behaviour via reactive-transport modelling using the 'glass reactivity with allowance for the alteration layer' (GRAAL) model $^{30,31}$ (see Fig. $1 \mathrm{~b}$ and "Methods"). The calculations included all the events that induced dilution or water loss in the measured

${ }^{1}$ BRGM, French Geological Survey, 45060 Orleans, France. ${ }^{2}$ Andra, 1-7 rue Jean Monnet, Chatenay-Malabry 92298, France. *email: m.debure@brgm.fr 
a)

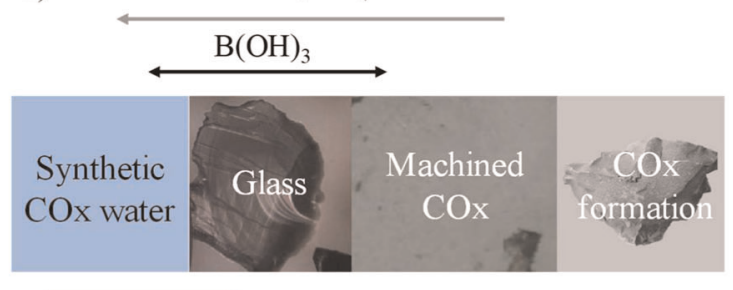

$\mathrm{HDO}, \mathrm{I}$
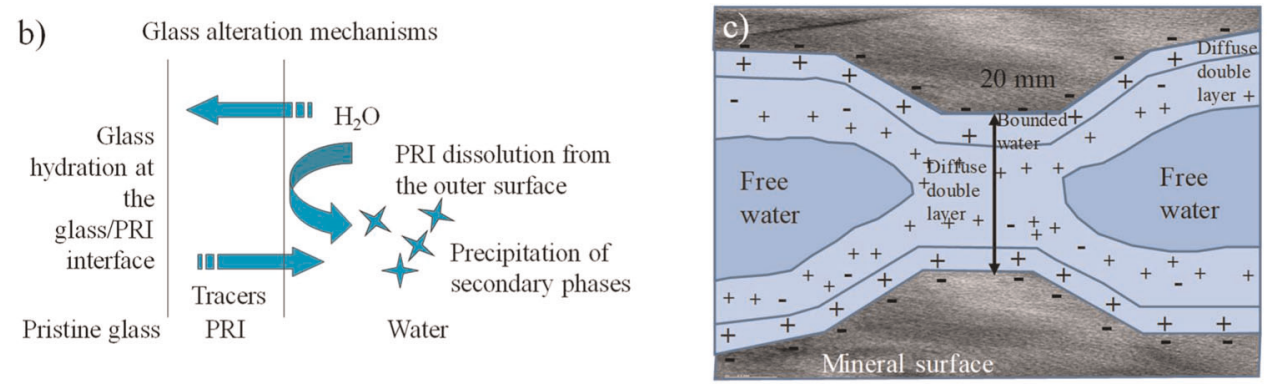

Fig. 1 Experimental scheme and mechanisms involved in the modelling. a The four modelled compartments involve the central circulation chamber filled with synthetic COx water, glass, machined COx claystone, and COx formation. The filters are not shown. The scheme also shows the direction of tracer diffusion. Deuterium (HDO) and $\mathrm{I}^{-}$are injected into the synthetic water. Boron derives from the glass. Both $\mathrm{Br}^{-}$and $\mathrm{NH}_{4}{ }^{+}$derive from the COx claystone. b Predominant mechanisms that occur during glass alteration, which take into account the glasscorrosion model known as GRAAL. PRI indicates the passivating reactive interface (see Methods and Supplementary Information 4). c Discretisation of the pore using a charge-free solution and Double Diffuse Layer (DDL) that forms the basis of the multi-component diffusion model in the clay systems (machined COx and COx formation) ${ }^{19,47}$

concentrations. Unexpected events occurred during the experiment (i.e., leaks and pressure loss), in addition to regular sampling, induced a decrease in the solution volume in the test chamber (see Supplementary Information 3).

\section{Calibration of the transport parameters}

Before deciphering the complexity of the system's reactivity, the transport parameters must be calibrated on the non-reactive species. Deuterium and $\mathrm{I}^{-}$were the tracers that circulate in the borehole, whereas $\mathrm{Br}^{-}$was the non-reactive species present in the pristine COx porewater. Chlorine was initially present in both the borehole solution and in the pristine COx porewater. The observed sharp variations in the concentrations shown in Fig. 2 were due to unexpected events that occurred during the experiment (i.e., leaks and pressure loss).

The set of parameters described by Appelo et al. ${ }^{19}$ to model a previous in situ experiment carried out in the URL was tested to reproduce the evolution of deuterium, $\mathrm{I}^{-}, \mathrm{Br}^{-}$, and $\mathrm{Cl}^{-}$as a function of time in our experiment (Table 1). Using these parameters, the deuterium (Fig. 2a), $\mathrm{I}^{-}, \mathrm{Br}^{-}$, and $\mathrm{Cl}^{-}$were satisfactorily reproduced (Fig. 2 b-d).

Slower diffusion associated with $\mathrm{I}^{-}, \mathrm{Br}^{-}$and $\mathrm{Cl}^{-}$was due to both the smaller accessible porosity (anionic exclusion) and larger tortuosity factor (Table 1). lodine, $\mathrm{Br}^{-}$and $\mathrm{Cl}^{-}$had identical diffusion coefficients and exhibited negligible retention. This result indicates that both inside (from the pristine COx formation to the borehole) and outside (from the borehole to the pristine COx formation) anionic tracers diffused at a similar rate. ${ }^{32}$ We noticed a slight increase in $\mathrm{Cl}^{-}$in the model while the actual data shows initially high $\mathrm{Cl}^{-}$, which remained the same or slightly decreased over time. This mechanism was already observed by Vinsot et al. ${ }^{33}$ Drilling induced desaturation around the borehole, which finally led to the precipitation of salt. When saturated, the inflow water diluted the salt that had already precipitated in the COx. The inflow of pristine pore water and diffusion of $\mathrm{Cl}^{-}$from the test interval into the field rock surrounding the test interval caused the slight decrease in the $\mathrm{Cl}^{-}$concentration until equilibrated with the COx porewater value via diffusion from the claystone in the test interval.

Lithium is usually used as a cationic tracer of COx claystone ${ }^{19}$ despite its reactivity with the COx exchanger (i.e., cations in the interlayer planes of the clay particles). Similarly, $\mathrm{Li}^{+}$is usually used as a tracer of glass alteration, such as $\mathrm{B}(\mathrm{OH})_{3}$. In our experiment, $\mathrm{Li}^{+}$concentrations represented the sum of two $\mathrm{Li}^{+}$sources: in situ COx porewater diffusion and glass alteration. When glass corrosion induced $\mathrm{a} \mathrm{Li}^{+}$concentration that was significantly higher than the $\mathrm{Li}^{+}$concentration in porewater, $\mathrm{Li}^{+}$was used as a glass-alteration tracer. Nonetheless, this would underestimate the amount of glass corrosion due to its interaction with the COx claystone.

To assess the cationic diffusion coefficient, instead of $\mathrm{Li}^{+}$, we can use $\mathrm{NH}_{4}^{+}$as an alternative method even if it also interacts with the COx exchanger (Table 1). The model sufficiently described the $\mathrm{NH}_{4}{ }^{+}$concentrations (Fig. 2e). Hence, the porewater diffusion coefficients $\left(D_{p}\right)$ of the ions were assessed based on a previous study, as well as the tortuosity factor $\left(v^{2}\right) .^{19}$

\section{Evidence from the solution analysis}

In the in situ experiment, the composition of the water that circulated in the borehole was measured (Fig. 3). Glass corrosion can be observed based on the increase in its constituents in the solution ( $\mathrm{B}, \mathrm{Li}^{+}, \mathrm{Si}, \mathrm{Na}^{+}$, etc.). Sodium released by the glass was more difficult to detect due to its initial presence in the COx clay rock. The experiment and model showed that glass dissolution only accounts for $10 \%$ of the $\mathrm{Na}^{+}$concentration (Fig. 3). Despite its potential interaction with the $\mathrm{COx}$ clay rock, $\mathrm{Li}^{+}$leaching was consistent with B leaching (Fig. 4a). The concentration of $\mathrm{Li}^{+}$ involved in glass corrosion was 50 times higher than that in the clay rock, allowing it to be considered as a possible tracer of glass alteration. This result agrees with laboratory experiments at $90^{\circ} \mathrm{C}$ that demonstrate that $\mathrm{Li}^{+}$release eventually becomes congruent compared with $\mathrm{B}$ after a previous stage where $\mathrm{Li}^{+}$exchanges with clay minerals. ${ }^{27}$ The magnesium concentration decreased in the first 400 days of reaction before it reached a steady-state that was 
a)

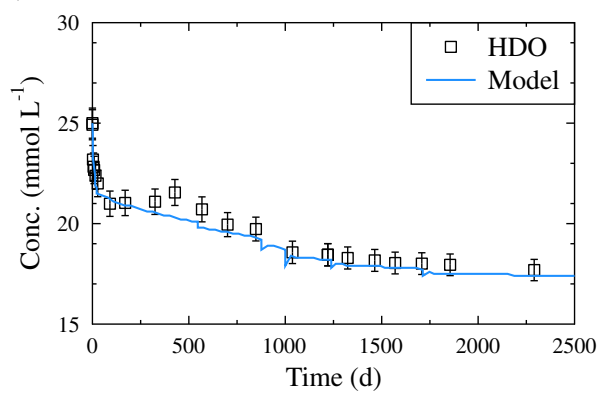

c)

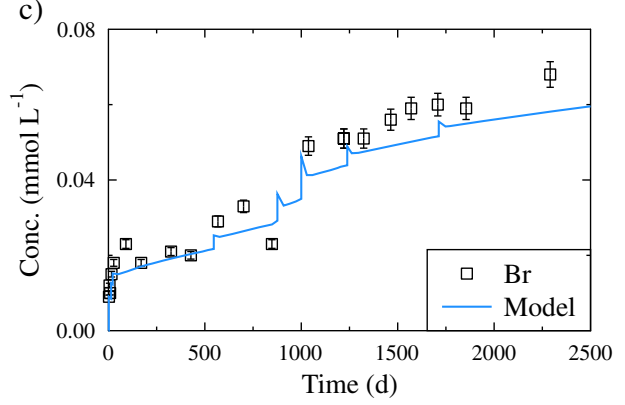

e)

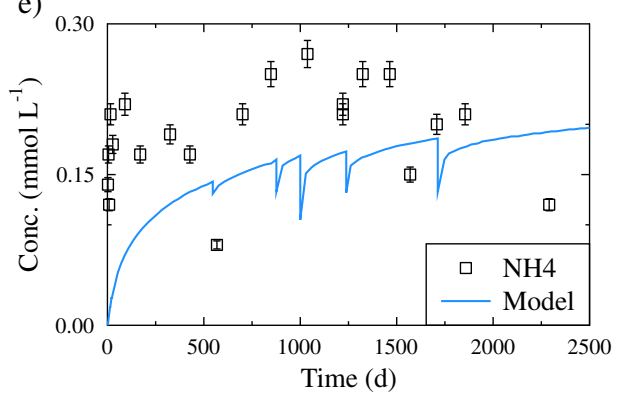

b)

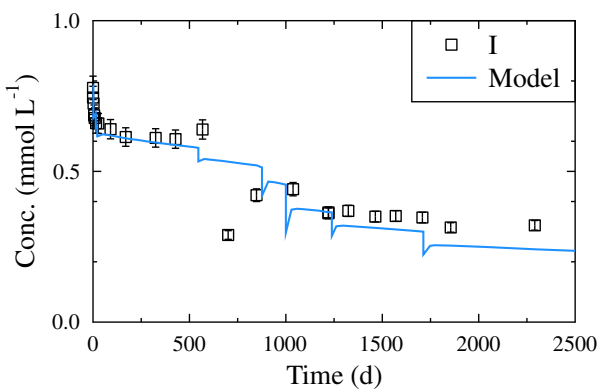

d)

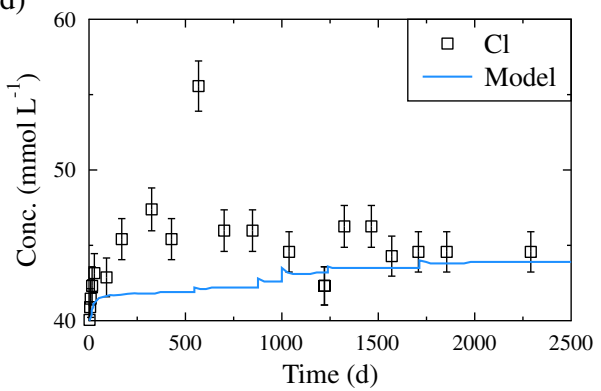

Fig. 2 A comparison of the experimental and modelled concentrations of the four non-reactive tracers $\left(\mathrm{HDO}^{-} \mathrm{I}^{-}, \mathrm{Br}^{-}\right.$, and $\left.\mathrm{Cl}^{-}\right)$and one reactive tracer $\left(\mathrm{NH}_{4}^{+}\right)$for the in situ glass corrosion diffusion experiment in COx clay rock. Deuterium and I- decrease with time since they are added to the initial solution that circulated in the clay. Bromide, $\mathrm{Cl}^{-}$, and $\mathrm{NH}_{4}^{+}$are initially absent in the solution and diffuse from pristine $\mathrm{COx}$ claystone. The analytical uncertainties are $5 \%$

lower than the porewater concentration, similar to $\mathrm{Ca}^{2+}$ (Fig. 3). The $\mathrm{pH}$ rapidly increased to its final value of 7.6 despite appearing to decrease towards the porewater value (7.2) between days 91 and 547. Silicon rapidly increased and then decreased from day 324 , similar to $\mathrm{B}$ and $\mathrm{Li}^{+}$. Aluminium was only occasionally detected in the solution despite its high content in the SON68 glass (Fig. 3).

The slow and constant decrease in Si after day 324 indicates both its consumption by secondary-phase precipitation ${ }^{34,35}$ and diffusion in the field. Low aluminium concentrations, as well as magnesium and calcium consumption in the solution, support the formation of secondary phases in the experiment.

Glass alteration: normalised mass losses and glass-corrosion rates The normalised mass loss (NL) (see "Methods") verifies that the glass-alteration rate was maximal during the first 28 days of reaction $\left(8.7 \times 10^{-3} \mathrm{~g} \mathrm{~m}^{-2} \mathrm{~d}^{-1}\right)$, decreased between days 90 and $324\left(2.3 \times 10^{-3} \mathrm{~g} \mathrm{~m}^{-2} \mathrm{~d}^{-1}\right)$, and then apparently decreased to attain a steady-state after day 1000 , which was $3.9 \times 10^{-4} \mathrm{~g} \mathrm{~m}^{-2}$ $\mathrm{d}^{-1}$ (Fig. 4a). The NL values for $\mathrm{B}$ and $\mathrm{Li}^{+}$were similar, whereas the rate for $\mathrm{Na}^{+}$was higher because of contributions from the $\mathrm{COx}$ porewater. A decrease in the glass corrosion rate occurred with the stabilisation of $\mathrm{Mg}^{2+}$ in the solution. Based on the $\mathrm{B}$ concentration, the altered glass represented $3.4 \mathrm{wt}$. \% of the pristine glass after day 324. Both $\mathrm{B}$ and $\mathrm{Li}^{+}$then decreased and, therefore, the quantity of the altered glass could not be assessed further or would become smaller with time due to those lower concentrations (2.1 wt. \% at day 2291).

Modelling has proven to be useful for assessing the expected glass alteration. However, it does not reproduce the decrease in $B$ observed in the experiment after 324 days of reaction (Fig. 3). The glass-dissolution rates calculated from the model were consistent with the experimental results until day $324\left(1.2 \times 10^{-2} \mathrm{~g} \mathrm{~m}^{-2} \mathrm{~d}^{-1}\right.$ in the first 28 days and $1.8 \times 10^{-3} \mathrm{~g} \mathrm{~m}^{-2} \mathrm{~d}^{-1}$ between days 90 and 324). However, $B$ still increased and the glass-corrosion rate slowed to $2.1 \times 10^{-4} \mathrm{~g} \mathrm{~m}^{-2} \mathrm{~d}^{-1}$ between days 324 and 1000 and stabilized at $6.8 \times 10^{-5} \mathrm{~g} \mathrm{~m}^{-2} \mathrm{~d}^{-1}$ after. This rate was two times lower than the SON68 residual corrosion rate measured after 11 years in pure water $\left(1.7 \times 10^{-4} \mathrm{~g} \mathrm{~m}^{-2} \mathrm{~d}^{-1} \text { at } 90^{\circ} \mathrm{C}\right)^{36}$ and twenty times lower than that measured in the $\mathrm{COx}$ porewater at $90^{\circ} \mathrm{C}$ (Supplementary Tables 6, 7). ${ }^{15}$ The glass-corrosion rate measured in our in situ experiment is in the range of values from the literature (see Supplementary Table 7). However, it is still two times higher than the residual rate measured in the COx claystone with flow in the experiments at $35^{\circ} \mathrm{C}\left(2.6 \times 10^{-5} \mathrm{~g} \mathrm{~m}^{-2} \mathrm{~d}^{-1}\right)^{37}$ but more than two orders of magnitude lower than the forward dissolution rate in $\mathrm{COx}$ water $\left(1.1 \times 10^{-2} \mathrm{~g} \mathrm{~m}^{-2} \mathrm{~d}^{-1}\right){ }^{38}$ The changes in the glass surface area-to-solution volume ratio do not allow for a full comparison among the different experiments. 
Table 1. The initial borehole solution and modelled porewater concentration (expressed in mmol L-1), water diffusion coefficient $\left(D_{\mathrm{w}}\right)$ for the reservoir, filters and glass compartment, porewater diffusion coefficient $\left(D_{\mathrm{p}}\right)$, tortuosity factors $\left(\mathrm{v}^{2}\right)$, and complexation constants for COx (machined and field)

\begin{tabular}{|c|c|c|c|c|c|c|}
\hline & $\begin{array}{l}\text { Initial } \\
\text { borehole } \\
\text { solution }\end{array}$ & $\begin{array}{l}\text { Model } \\
\text { pristine } \\
\text { porewater }\end{array}$ & $\begin{array}{l}D_{\mathrm{w}} \\
\left(10^{-9}\right. \\
\left.\mathrm{m}^{2} \mathrm{~s}^{-1}\right)\end{array}$ & $\begin{array}{l}D_{\mathrm{p}} \\
\left(10^{-10}\right. \\
\left.\mathrm{m}^{2} \mathrm{~s}^{-1}\right)\end{array}$ & $v^{2}$ & $\log K$ \\
\hline $\mathrm{pH}$ & 7.38 & 7.05 & 9.31 & 12.62 & 7.36 & 2.2 \\
\hline $\mathrm{Li}^{+}$ & 0 & 0.055 & 1.03 & 1.75 & 5.90 & -0.8 \\
\hline $\mathrm{Na}^{+}$ & 41.1 & 49.00 & 1.33 & 1.80 & 5.90 & -0.7 \\
\hline $\mathrm{K}^{+}$ & 1.0 & 1.00 & 1.96 & 2.66 & 5.90 & -0.26 \\
\hline $\mathrm{NH}_{4}^{+}$ & 0 & 0.25 & 1.98 & 2.68 & 5.90 & -0.23 \\
\hline $\mathrm{Mg}^{2+}$ & 5.2 & 5.20 & 0.705 & 0.96 & 5.90 & -0.82 \\
\hline $\mathrm{Ca}^{2+}$ & 8.2 & 7.64 & 0.793 & 1.08 & 5.90 & -0.70 \\
\hline $\mathrm{Sr}^{2+}$ & 0.2 & 0.24 & 0.794 & 1.08 & 5.90 & -0.52 \\
\hline $\mathrm{Cl}^{-}$ & 39.1 & 45.00 & 2.03 & 0.44 & 18.4 & \\
\hline Alkalinity & 0 & 3.78 & 1.18 & 0.26 & 18.4 & \\
\hline $\mathrm{SO}_{4}{ }^{2-}$ & 13.8 & 11.25 & 1.07 & 0.23 & 18.4 & \\
\hline $\mathrm{Br}^{-}$ & 0 & 0.10 & 2.01 & 2.76 & 18.4 & \\
\hline $\mathrm{I}^{-}$ & 0.78 & 0.035 & 2.03 & 2.73 & 18.4 & \\
\hline $\mathrm{OH}^{-}$ & & & 5.27 & 1.15 & 18.4 & \\
\hline $\mathrm{H}_{4} \mathrm{SiO}_{4}$ & 0 & 0.18 & 1.1 & 1.49 & 7.36 & \\
\hline $\mathrm{B}(\mathrm{OH})_{3}{ }^{\mathrm{a}}$ & 0 & 0 & 1.64 & 2.23 & 7.36 & \\
\hline HDO & $\begin{array}{l}25.0 \\
(444.3 \% \text { o) }\end{array}$ & $\begin{array}{l}16.6 \\
(-40.7 \% \circ)\end{array}$ & 2.27 & 2.92 & 7.36 & \\
\hline \multicolumn{7}{|c|}{$\begin{array}{l}\text { The porosity at the centre of the test interval and in the glass area was } \\
100 \%, 30 \% \text { in the filter, and } 18 \% \text { in the COx claystone } \\
\text { a } \mathrm{At} \mathrm{pH}=7.5, \mathrm{~B}(\mathrm{OH})_{3} \text { is the predominant form (see Supplementary Fig. } 4 \text { for } \\
\text { details) }\end{array}$} \\
\hline
\end{tabular}

However, our results show that the modelled glass-dissolution rate does not significantly increase despite the considerable amount of $\mathrm{Mg}^{2+}$ and $\mathrm{Fe}^{2+}$ available in the COx claystone. Fluxes of chemical species was slow because of the low diffusability in the clay rock. Therefore, the transfer of elements consumed by secondary-phase precipitation (i.e., $\mathrm{Ca}^{2+}, \mathrm{Mg}^{2+}$, and $\mathrm{Fe}^{2+}$ ) was not sufficiently rapid to sustain a high glass corrosion rate. According to the modelling results, the altered-glass thickness can be estimated from the $B$ concentration at $548 \mathrm{~nm}$, where the Passivating Reactive Interface (PRI) accounts for $45-50 \%$ (Fig. 4b). This thickness was two times greater than that calculated from the experimental data $(299 \mathrm{~nm})$. Modelling results led to a quantity of altered glass of $\sim 3.9 \mathrm{wt}$ \%, instead of 2.1 wt. \%.

\section{Modelling of glass corrosion: PRI, altered layer, and interactions} with COx claystone

The model shows that the PRI remained small during the 50 first days of reaction and then increased, whereas secondary-phase precipitation (Fig. 5b) did not inhibit the precipitation of the nonpassivating gel end members (see Supplementary Information 4 for the description of the end members) (Fig. 5a). The secondary phases consumed elements from the glass: pimelite controlled $\mathrm{Ni}^{+}$while zincsilite, powellite, hydroxyapatite, and nontronite governed $\mathrm{Zn}^{2+}, \mathrm{MoO}_{4}{ }^{2-}, \mathrm{HPO}_{4}{ }^{2-}$, and $\mathrm{Fe}^{2+}$, respectively (Supplementary Fig. 5). The traces (i.e., $\mathrm{Ni}^{2+}, \mathrm{Zn}^{2+}, \mathrm{MoO}_{4}{ }^{2-}$, and $\mathrm{HPO}_{4}{ }^{2-}$ ) did not drive glass alteration because the formed secondary phases required less $\mathrm{Si}$ than the glass. For $\mathrm{Fe}^{2+}$, an additional source was derived from the COx claystone, especially from pyrite dissolution. Therefore, nontronite precipitation sustained glass alteration. However, the PRI formed increased significantly when the precipitation rate of the nontronite decreased (Fig. 5b) after day 50. The $\mathrm{Mg}^{2+}$ source also originated from the COx claystone and consumed $\mathrm{Si}$ from the glass due to the precipitation of saponite (Fig. $5 \mathrm{~d}$ ). The PRI quantity decreased to a value similar to the COx claystone, as well as the injected solution, whereas the non-passivating end members increased (Fig. 5c), along with the secondary phases (Fig. $5 \mathrm{~d}$ ). We note that glass corrosion was higher at the glass/COx claystone interface than that at the water/ glass interface. At the glass/COx claystone interface, we see a higher amount of precipitated secondary minerals and a higher content in non-passivating end members. The mineralogical changes were slight in the COx claystone (Supplementary Fig. 6), such that the largest mineralogical modifications in the COx claystone occurred at the interface with glass. Calcite and chlorite dissolved (Fig. 5e, f), whereas there was precipitation dolomite, and celestite. Illite and pyrite revolved around their equilibrium and were, thus, dissolved and precipitated during the experiment. However, these changes were so minuscule that precipitation and dissolution cannot be observed in Fig. 5e, f. The highest modifications of the clay exchanger also appeared at the interface with glass (Fig. $5 \mathrm{~g}$ ). The exchanger was depleted in $\mathrm{Ca}^{2+}$ and $\mathrm{Mg}^{2+}$ and predominantly enriched in $\mathrm{Na}^{+}$and $\mathrm{Li}^{+}$in the entire core, whereas glass dissolution had less of an effect on the exchanger in the field (Fig. 5h).

\section{Modelling of elemental diffusion in the field}

Our modelling also allows an assessment of the concentration gradient for the different elements from the test chamber to the field by considering both their diffusion and chemical reactivity (i.e., retention and precipitation). Deuterium diffused over $75 \mathrm{~cm}$ into the field, whereas $\mathrm{I}^{-}$only reached $55 \mathrm{~cm}$ due to anionic exclusion (Fig. 6a, b). Glass corrosion released $\mathrm{Na}^{+}$, whose concentration increased by $10 \%$ at the centre of the test interval compared with the field value (Fig. $6 \mathrm{c}$ ). At the same time, there was an increase in the $\mathrm{pH}$ value due to glass dissolution in the glass area. Therefore, we observed a $\mathrm{pH}$ gradient in the machined COx area, as well as in the field (Fig. 6d). Boron, whose retention coefficient was not initially considered, diffuses at the same rate as deuterium and, thus, reached $75 \mathrm{~cm}$ in the field (Fig. 6e), whereas $\mathrm{Li}^{+}$only reached $30 \mathrm{~cm}$ (Fig. $6 \mathrm{f}$ ) due to its reactivity. The diffusion distance decreased to $20 \mathrm{~cm}$ when boron was considered to be sorbed by clay (Fig. 6e). Silicon increased in the area with glass dissolution. Its diffusion was rather limited because of secondaryphase precipitation at the interface between the glass and COx claystone (Fig. $6 \mathrm{~g}$ ). Simultaneously, $\mathrm{Mg}^{2+}$ was lower in the glass area than in the field (Fig. 6h), displaying a diffusion profile between the two areas. Iron was characterized by a diffusion profile as well, but its content in the glass area is higher than its content in the field because unlike $\mathrm{Mg}^{2+}$, iron is a component of both the pristine glass and the COx (Supplementary Fig. 7d). Their diffusion profiles result from the interplay between their diffusion and reactivity. Secondary-phase precipitation in the glass area consumed both $\mathrm{Mg}$ and $\mathrm{Fe}$. In addition, the porewater $\mathrm{Mg}^{2+}$ concentration was driven by the ion-exchange reaction and its release from the COx clay exchanger. This latter process was also influenced by the increase of $\mathrm{Na}^{+}$and $\mathrm{Li}^{+}$in the solution, which led to higher retention in the exchanger and, therefore, limited diffusion in the field compared with $\mathrm{B}$.

Glass corrosion in geological media: mechanisms involved

The in situ diffusion experiment revealed that the measured glass corrosion rate was lower than its forward dissolution rate measured in COx porewater; the corrosion rate rapidly decreased to reach the range of the long-term values measured in laboratory experiments. The glass-corrosion mechanisms were similar to those identified in previous studies. ${ }^{12,15}$ The glass-alteration rate increased until Si reached a steady-state. Then, a rate-drop regime 
a)

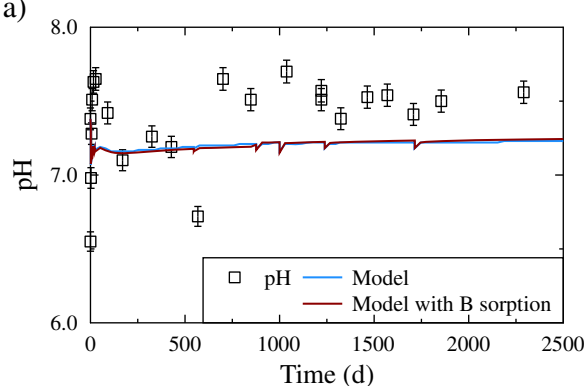

c)

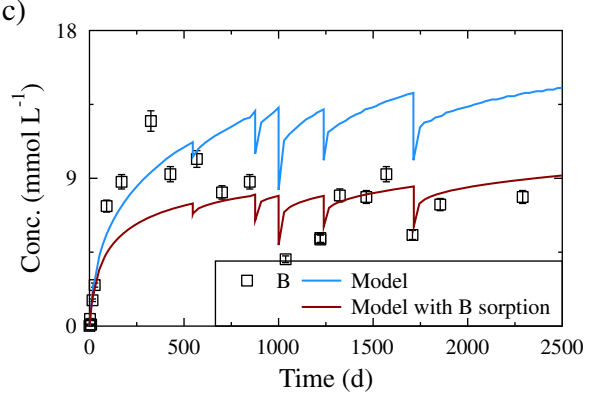

e)

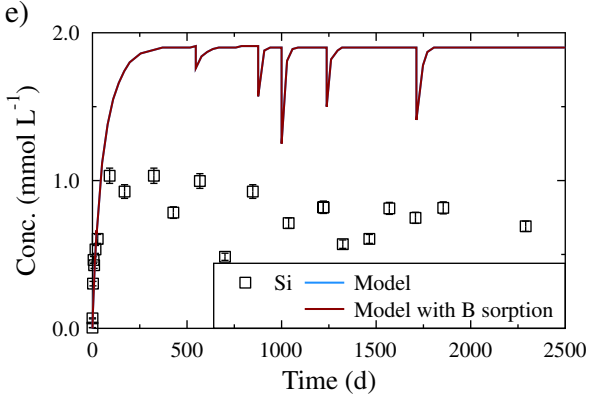

g)

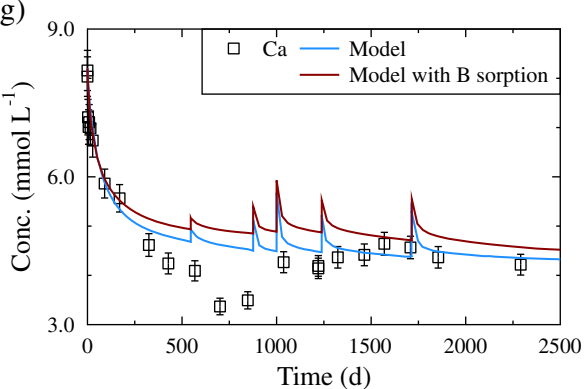

i)

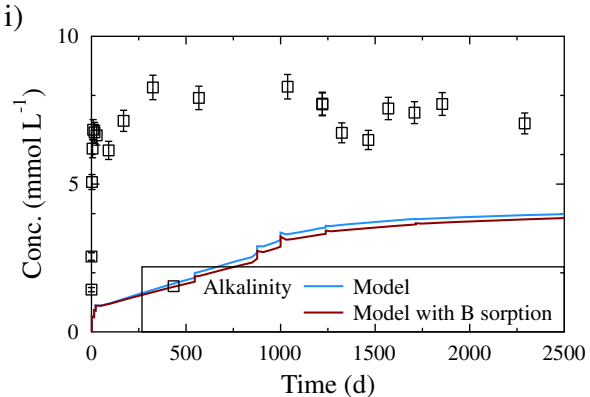

b)

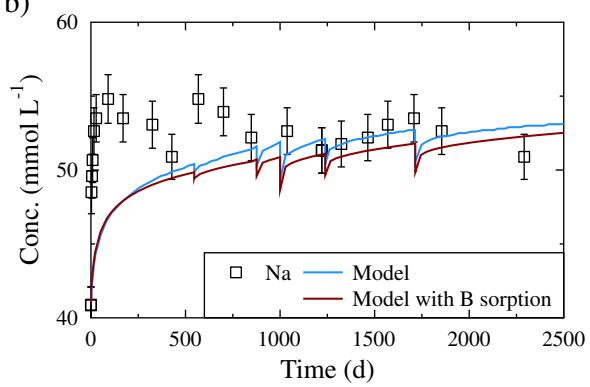

d)

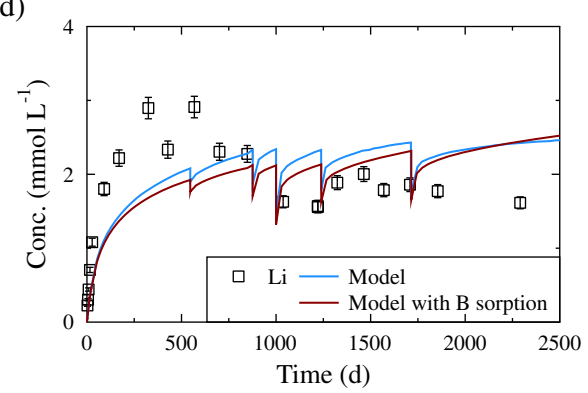

f)

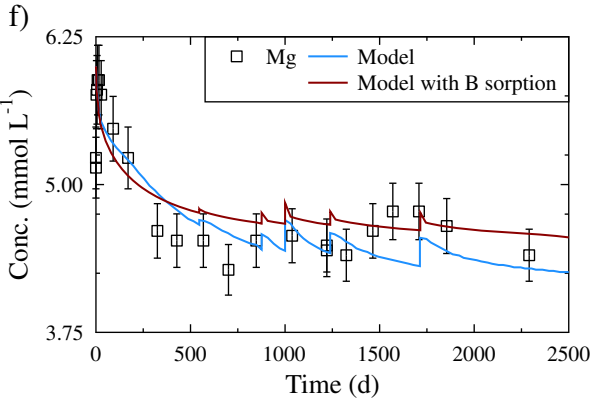

h)

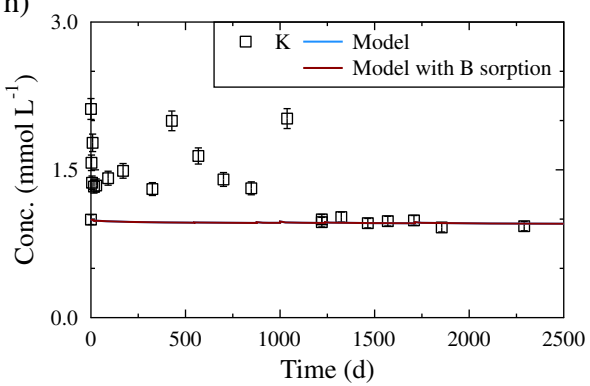

j)

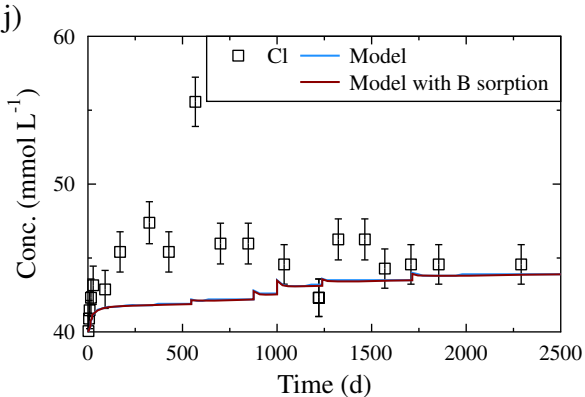

Fig. 3 A comparison between the modelled and experimental $\mathrm{pH}$ and concentrations in the in situ glass corrosion diffusion experiment in the COx clay rock at Bure (F). a pH evolution as a function of time, $\mathbf{b} \mathrm{Na}^{+}$concentration as a function of time, $\mathbf{c}$ B concentration as a function of time, $\mathbf{d} \mathrm{Li}^{+}$concentration as a function of time, e Si concentration as a function of time, $\mathbf{f} \mathrm{Mg}^{2+}$ concentration as a function of time, $\mathbf{g} \mathrm{Ca}{ }^{2+}$ concentration as a function of time, $\mathbf{h ~ K} \mathbf{K}^{+}$concentration as a function of time. The behaviour of the other elements is slightly modified when considering B sorption on clay. Considering B sorption significantly improves the long-term (>1,000 days) modelled B concentration. The analytical uncertainties are $5 \%$ 

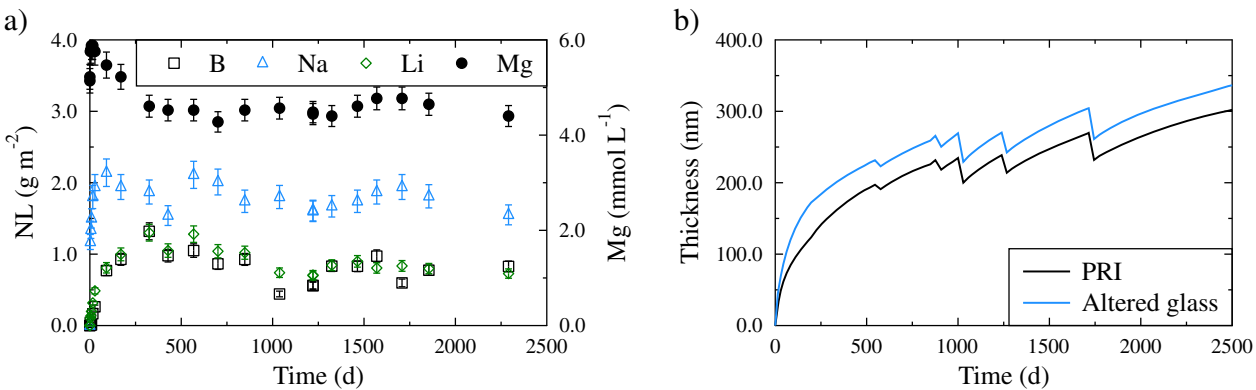

Fig. 4 Experimental (normalised mass losses) and modelled (altered thickness) glass corrosion indicators. a Normalised $\mathrm{B}, \mathrm{Li}^{+}$, and $\mathrm{Na}^{+}$mass losses and $\mathrm{Mg}^{2+}$ concentrations as a function of time during the in situ glass-corrosion experiment (the uncertainties are $9 \%$ ). $\mathbf{b}$ Total PRI and altered glass thicknesses calculated from the modelled B and altered-glass layer end members

occurred due to the formation of gel (porous, amorphous, and hydrated compound) on the glass surface. This formation occurs because of precipitation and in situ condensation of Si and other cations from the glass or the solution. ${ }^{9,39}$ Based on the modelling describing the evolution of measured concentrations, secondaryphase precipitation is predicted, which delays PRI formation that occurs as soon as the secondary-phase precipitation rate decreases. The resulting silica consumption prevents PRI formation due to recombination with elements from the solution and $\mathrm{COx}$ claystone dissolution. $\mathrm{Mg}^{2+}$ and $\mathrm{Fe}^{2+/ 3+}$ are identified as $\mathrm{Si}$ consumers as they form Fe or Mg-bearing silicates. ${ }^{12-14,20,21,40}$ Precipitation of these silicates depends on the concentration and availability of the ions, temperature, and $\mathrm{pH}$. Considering the chemistry of the solution after 2291 days of reaction, Mg-bearing silicate precipitation cannot occur below a pH of 7.0, whereas Febearing phases can precipitate at a $\mathrm{pH}$ as low as 4.0 and pe ranging from -2 to 15 depending on the $\mathrm{pH}$ (Supplementary Fig. 9). ${ }^{16,21}$ Such $\mathrm{pH}$ and pe conditions are in agreement with the experimental and modelling conditions encounter in this study (Supplementary Table 1 and Fig. 5). The experimental conditions allow precipitation of secondary phases as the $\mathrm{pH}$ rapidly increases from 7.2 to 7.6 due to initially fast corrosion of glass. However, Fe- or Mg-silicate precipitation releases protons into the solution to form saponite, as expressed in Eq. (1):

$$
\begin{aligned}
3 \mathrm{Mg}^{2+} & +0.34 \mathrm{Na}^{+}+0.34 \mathrm{Al}^{3+}+3.66 \mathrm{H}_{4} \mathrm{SiO}_{4} \rightarrow \text { Saponite } \\
& +7.36 \mathrm{H}^{+}+2.64 \mathrm{H}_{2} \mathrm{O} .
\end{aligned}
$$

$\mathrm{pH}$ decrease has two main consequences: it increases the interdiffusion coefficient within the PRI and changes the solubility of the mineral phases and gel end members. It can be speculated that secondary-phase precipitation stops once the $\mathrm{pH}$ has sufficiently decreased. However, the interdiffusion process supplies alkaline elements to the solution and produces hydroxyl $\left(\mathrm{OH}^{-}\right)$ions that can increase the $\mathrm{pH}$ and sustain secondary-phase precipitation. Therefore, magnesium concentration in the solution is reduced and the glass-corrosion rate increases. This mechanism drives the system in the first 324 days of the experiment. However, $\mathrm{Mg}^{2+}$ then stabilises (Fig. 3f) and the glass-corrosion rate is drastically reduced.

As the $\mathrm{pH}$ value remains nearly constant afterwards (within the uncertainties), we can infer that the $\mathrm{OH}^{-}$formed due to glass dissolution strictly outweighs the protons released into the solution via the formation of secondary phases. Therefore, Fe- or Mg-silicate precipitation does not increase the glass-corrosion rate. However, the alkalis released from the glass $\left(\mathrm{Na}^{+}\right.$and $\left.\mathrm{Li}^{+}\right)$ may modify the exchanger population in the COx core, which can lead to $\mathrm{Mg}^{2+}$ release into the solution. Nonetheless, this does not modify the overall balance between the reactions. The diffusive gradient of $\mathrm{Mg}^{2+}$ and $\mathrm{Fe}^{2+}$ between the glass and field area indicates that their transport is slower than their consumption because of secondary-phase precipitation, which limits glass alteration. Finally, despite the availability of $\mathrm{Mg}^{2+}$ and $\mathrm{Fe}^{2+}$ in the COx claystone, glass corrosion reaches a constant long-term rate that is higher than the residual rate measured in pure water but lower than that measured in groundwater. ${ }^{15}$

The dissolution and interdiffusion kinetics identified in pure water and the thermodynamic properties of the secondary phases and non-passivating gel are sufficient to describe SON68 glass corrosion in geological media. The best description of the experiment can be obtained considering hydrated saponite $\left(\mathrm{Na}_{0.34} \mathrm{Mg}_{3} \mathrm{Al}_{0.34} \mathrm{Si}_{3.66} \mathrm{O}_{10}(\mathrm{OH})_{2}: 3.84 \mathrm{H}_{2} \mathrm{O}\right)$ in the model. Hydrated saponite is the most stable saponite phase in the thermodynamic database but nontronite also formed, which is in agreement with previous laboratory experiments. ${ }^{23}$ Other Mg-silicates overestimate $\mathrm{Mg}^{2+}$ in the solution by $13 \%$ due to lower precipitation, whereas modifications of other elements remain within the uncertainties. Thus, exposure to field conditions did not cause complete dissolution of the primary $\mathrm{Mg}$-bearing phase (i.e., dolomite, clays, etc.), in contrast with previous observations on glass and dolomite interactions. ${ }^{12}$ In this study, glass corrosion is not influenced by $\mathrm{Mg}^{2+}$ availability due to the observed lower $\mathrm{pH}$ (7.6 instead of 9.0 in the previous study ${ }^{12}$ ) and limited species transport, which reduces glass alteration compared with that in batch conditions.

$\mathrm{B}$ and $\mathrm{Li}^{+}$are considered tracers of glass alteration and cannot precipitate or recondense as secondary phases. ${ }^{39}$ Their reduction and their anomalous behaviour after 546 days of reaction is not completely understood. The diffusion might explain this decrease, if the release rate of $B$ into the solution due to glass corrosion is lower than the diffusion rate in the field; however, the multicomponent diffusion calculations reject this hypothesis. Calcite precipitation does consume $B^{41,42}$ and $B$ sorbs onto clays in $a$ similar context. ${ }^{43-46}$ However, uptake would require a significant amount of $B$ in the calcite as only a negligible amount of a mineral is formed (of the order of micromoles). In clay, sorption is a twostep process of adsorption followed by incorporation in which $B$ may replace $\mathrm{Si}$ and $\mathrm{Al}$ at tetrahedral sites. ${ }^{44,45}$ Clays can retain as much as $110 \pm 22 \mu \mathrm{g}$ of $\mathrm{B}$ per gram of rock. ${ }^{43}$ Here, the modelling results are consistent with those of the field experiment. Only by dismantling the experiment, however, can we resolve the discrepancy between the modelling and solution analyses by measuring the thickness of the altered layer and comparing it with the thickness calculated based on the concentration of B leached into the solution.

To conclude, reactive-transport modelling of in situ glass alteration has revealed that nuclear-glass corrosion occurs through Si consumption by the elements $\left(\mathrm{Mg}^{2+}\right.$ and $\left.\mathrm{Fe}^{2+}\right)$ that originate from the solution or geological media and form secondary silicate phases. Si consumption delays the formation of the passivating interface, which tends to maintain a high glass corrosion rate. COx claystone introduces $\mathrm{pH}$ values that limit secondary-phase precipitation, and a steady-state is reached in only 500 days. Low $\mathrm{pH}$ slows secondary-phase precipitation, and 
a)

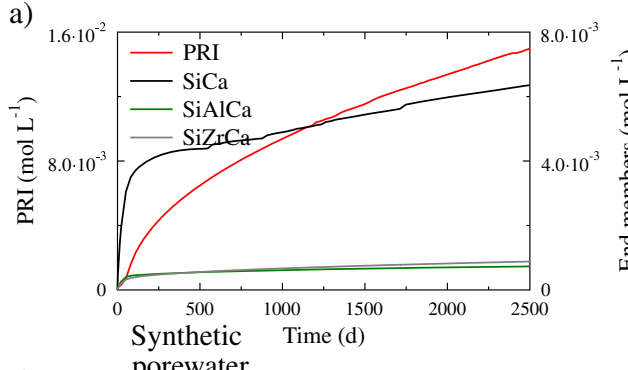

c)

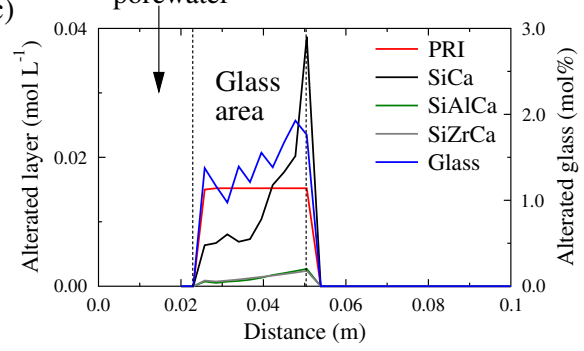

e)

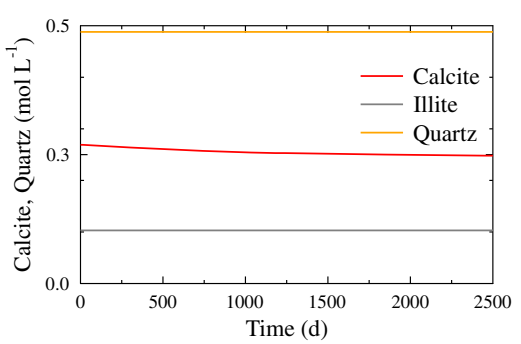

g)

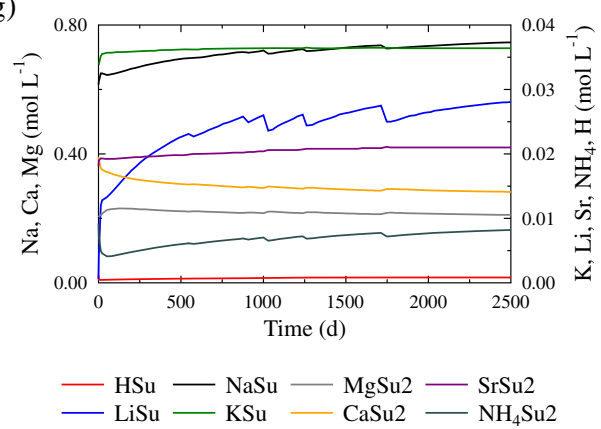

b)

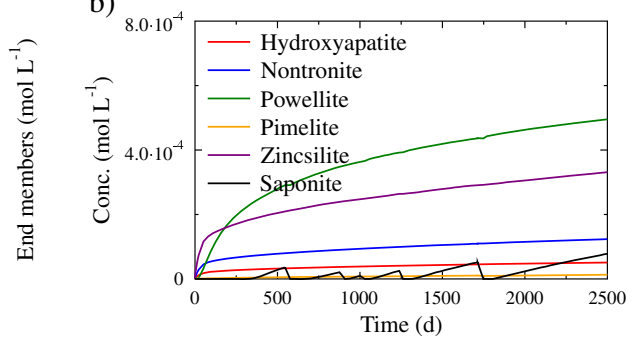

d)

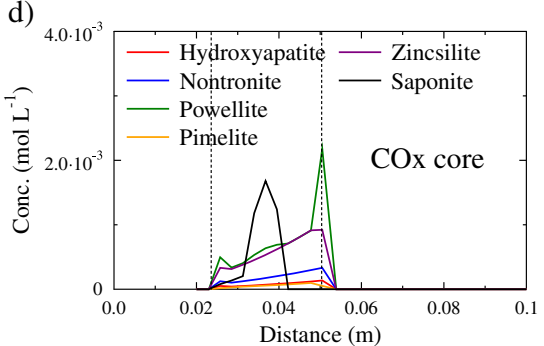

f)

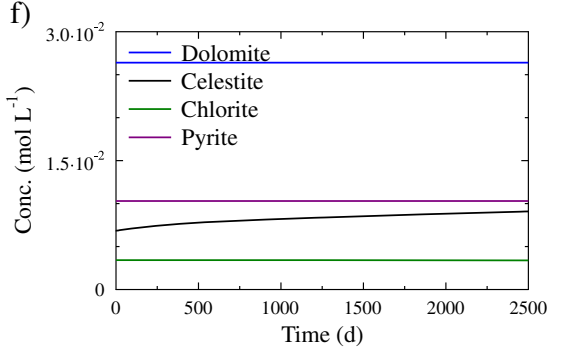

h)

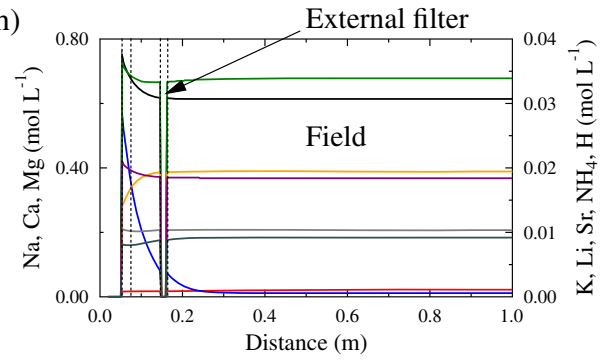

Fig. 5 Glass, altered glass layer, exchanger, primary and secondary minerals evolution with time and distance to the test interval. a Altered glass and PRI at the test interval (glass/water) interface. b Secondary crystallised phases (expressed in $\mathrm{mmol} \mathrm{L}^{-1}$ ) of the solution at the test interval (glass/water) interface. c Altered glass (mol\%), PRI and non-passivating end-members after 2500 days in the 'glass area.' d Secondary crystallised phases after 2500 days in the 'glass area.' e Calcite, illite, and quartz in the COx claystone at the interface with glass. $\mathbf{f}$ Dolomite, celestite, chlorite, and pyrite in the COx claystone at the interface with glass. $\mathbf{g}$ COx exchanger at the interface with glass. $\mathbf{h}$ The exchanger in the entire modelled domain (note that the exchanger is only present in clays, such that its value is zero in the other areas)

persists because glass dissolution yields $\mathrm{OH}^{-}$that balances $\mathrm{H}^{+}$ formed via secondary-phase precipitation.

The model proves useful for assessing the long-term corrosion rate of a nuclear glass; the rate is higher than the residual rate measured in pure water but lower than that found in $\mathrm{COx}$ porewater. Glass does not entirely dissolve in geological media despite an excess of elements that can increase its dissolution rate as commonly observed in the batch experiment. Finally, the influence of species transport from the field on glass corrosion rate is confirmed.

This study aimed to assess the mechanisms involved in glasscorrosion in the presence of nearfield materials. Once Si saturates the corrosion products of a canister and steel overpack containing HLW, the Fe effect becomes rather limited. The model accurately reproduces the in situ experiment and supports the identification of the main mechanisms that interact with the COx claystone during glass corrosion. These results, however, must be complemented by characterisation of the altered glass after dismantling the experiment. Our results will allow further investigations associated with the long-term behaviour of basaltic and nuclearglass over a larger spatio-temporal scale using multi-component modelling.

\section{METHODS}

Experimental description

The experimental setup consisted of equipment installed in a vertical descending borehole (MVE1202) and a water circulation/sampling module. The borehole equipment consisted of a complete mono packer, which included a $0.3-\mathrm{m}$-long test interval at the far end of the borehole and contained a COx core with a hollow cylindrical shape filled with glass powder (Fig. 1) surrounded by stainless-steel sintered filters 
a)

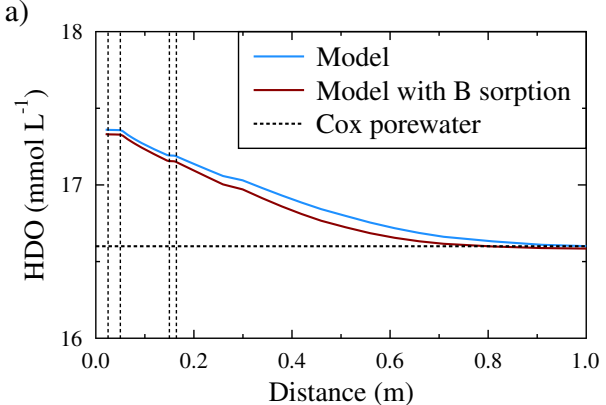

c)

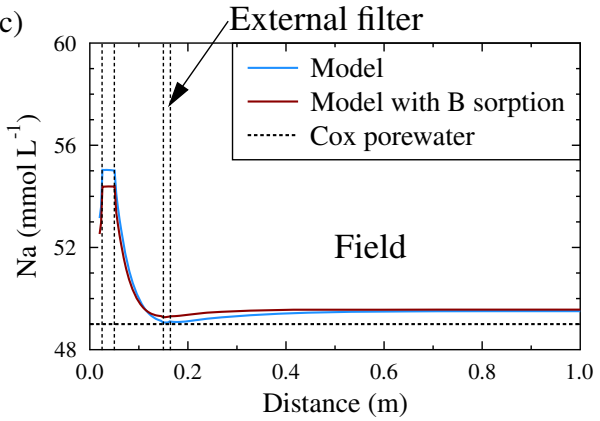

e)

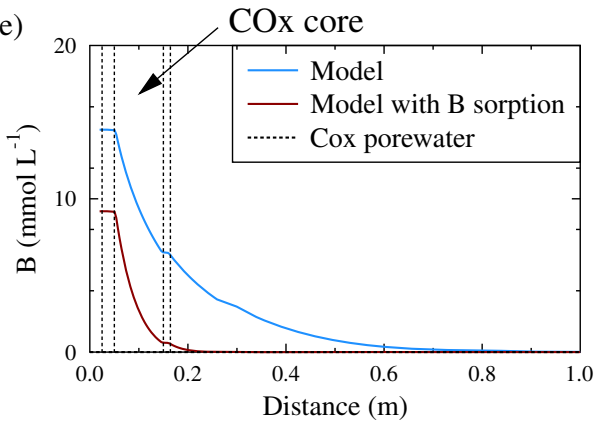

g)

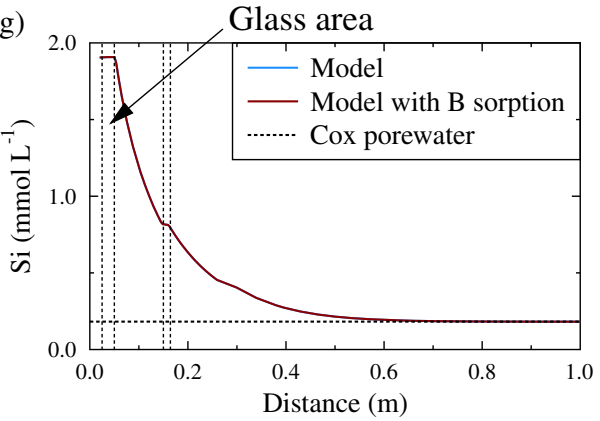

b)

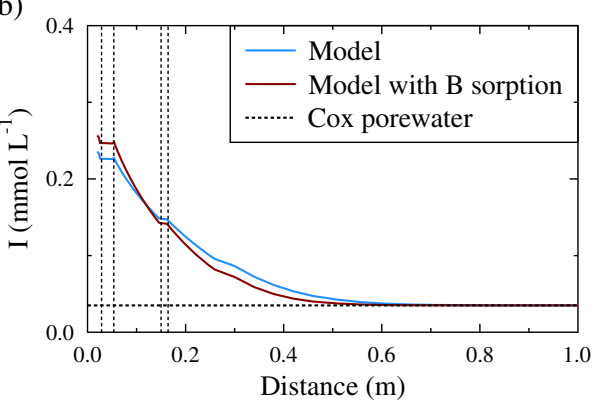

d)

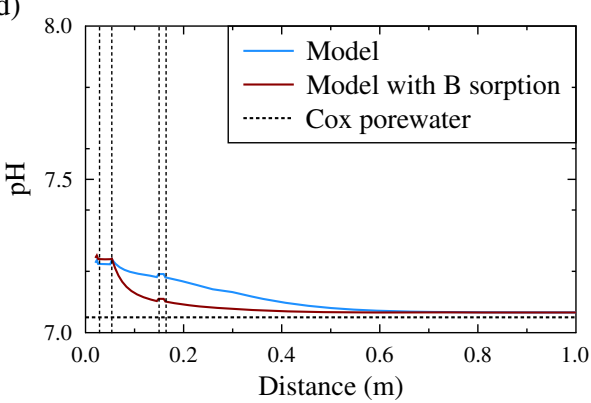

f)

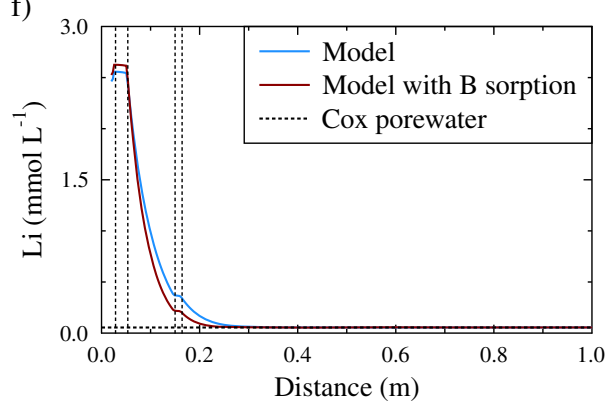

h)

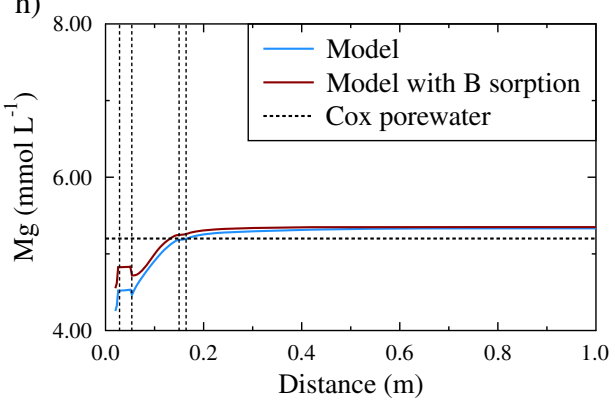

Fig. 6 Tracers and element diffusion in the modelled area after 2291 days of reaction. The core and field are the machined COx claystone and COx formation, respectively. The internal filter is not shown. Note that the difference observed for $\mathrm{Na}$ and Mg between the field concentration at large distances and the COx porewater is due to an initial equilibration with the exchanger

(Supplementary Fig. 1). The test interval was isolated by a 2-m-long packer inflated with water.

Initially, the test interval was closed and saturated with synthetic water. The solution flowed into the extraction line through a butyl bag reservoir equipped with a manometer, filter, flowmeter, pump (that enabled flow circulation), electrodes ( $\mathrm{pH}$ and $\mathrm{Eh}$ ) and samplers to finally be injected again into the test chamber (Supplementary Fig. 1). At each sampling time, a sampler was disconnected from the system using the by-pass. Based on a previous experiment ${ }^{47}$ and predictive modelling, ${ }^{48}$ the synthetic porewater composition simulated the porewater chemistry of the surrounding $\mathrm{COx}$ claystone.

Under disposal conditions, the kinetics of glass dissolution occurs in the residual rate stage when the glass is no longer exposed to high temperatures, such that the silica saturates the iron-corrosion products formed by the degradation of the steel canister. Therefore, iron-corrosion products are inactive with respect to glass corrosion. In addition, the thermal radiation of the glass implies a temperature that is lower than $50{ }^{\circ} \mathrm{C}$, which allows us to perform the test at field temperatures. In this in situ experiment, our objective was to attain, as rapidly as possible, the residual rate stage to study the long-term behaviour of the glass. To achieve diffusive conditions, the pressure in the test interval was increased to $40 \times 10^{5} \mathrm{~Pa}$ (=40 bars), which is approximately the expected pressure of the COx formation. A flow rate equal to $15 \mathrm{~mL} / \mathrm{min}$ was maintained between the interval and module located in the drift. The $\mathrm{pH}$, Eh, electrical conductivity, temperature, and mass were measured online to be able to collect the samples at predetermined times. 


\section{Glass preparation}

The SON68 glass (21.24 Si, $3.22 \mathrm{Ca}, 0.81 \mathrm{Li}, 1.98 \mathrm{Zn}, 5.35 \mathrm{~B}, 1.06 \mathrm{Cs}, 2.56 \mathrm{Al}$, $0.46 \mathrm{~K}, 0.34 \mathrm{Sr}, 0.62 \mathrm{Ba}, 7.82 \mathrm{Na}, 0.03 \mathrm{Sn}, 0.18 \mathrm{Co}, 0.04 \mathrm{Cr}, 0.17 \mathrm{Ni}, 0.31 \mathrm{Fe}$, $0.36 \mathrm{Mn}, 1.75 \mathrm{La}, 2.09 \mathrm{Nd}, 4.15 \mathrm{Ce}, 0.58 \mathrm{Pr}, 2.14 \mathrm{Zr}, 1.42 \mathrm{Mo}$ and $0.08 \mathrm{P}$ in wt. $\%$ of the element) was manufactured by CEA Marcoule (France) in 2009. The glass was melted in platinum-rhodium crucibles in an electric furnace at $1200^{\circ} \mathrm{C}$ for $\sim 4 \mathrm{~h}$ (including $3 \mathrm{~h}$ of refining) and then cast in a pre-heated graphite mould. The ingots were annealed at $530^{\circ} \mathrm{C}$ for $1 \mathrm{~h}$ in an electric oven and cooled to room temperature at a rate of $50^{\circ} \mathrm{C} / \mathrm{h}$. The glass was then crushed, milled, sieved, and washed according to Stokes' law to obtain a $160-250-\mu \mathrm{m}$-size fraction. The specific surface area determined by Brunauer-Emmett-Teller ${ }^{49} \mathrm{Kr}$ was $250 \mathrm{~cm}^{2} \mathrm{~g}^{-1}$.

\section{COx core preparation}

The COx core was drilled with a diameter of $290 \mathrm{~mm}$ and processed to obtain a length of $300 \mathrm{~mm}$ with a diameter of $101 \mathrm{~mm}$ for the central hole. During processing, a confinement shell surrounded the drill core. Despite caution, a single piece of COx claystone could not be processed (fractures/ cracks due to the tools and hard spot due to a fossil) and, therefore, a 300$\mathrm{mm}$ long piece was obtained by superimposing three blocks with sizes of 200,60 , and $40 \mathrm{~mm}$.

\section{Synthetic-water preparation}

A synthetic-water representative of the COx porewater was prepared using boiled and outgassed Millipore Milli- ${ }^{\circledR}{ }^{18}-\mathrm{M} \Omega$ water and analytical grade salts $\left(\mathrm{CaSO}_{4} .2 \mathrm{H}_{2} \mathrm{O}, \mathrm{MgSO}_{4} .7 \mathrm{H}_{2} \mathrm{O}, \mathrm{KCl}, \mathrm{NaCl}, \mathrm{SrCl}_{2} \cdot 6 \mathrm{H}_{2} \mathrm{O}\right.$, and $\left.\mathrm{Na}_{2} \mathrm{SO}_{4}\right)$. The preparation was done in a glove box with an atmosphere that approached that in the field and equilibrated with carbonates $\left(99 \% \mathrm{~N}_{2} / 1 \% \mathrm{CO}_{2}\right)$. The synthetic porewater chemistry was based on the porewater chemistry modelled in a COx clay rock, ${ }^{48}$ whose composition is listed in Table 1.

\section{Solution analysis and interpretations}

The unit consisted of eight samplers of $25 \mathrm{~mL}$ and 12 samplers of $10 \mathrm{~mL}$ in stainless steel with a bypass. The solution circulated in the samplers. Leachate sampling was done by removing a segment of the circuit corresponding to the volume of a sampler that was initially placed in the sample port of the module. In the analytical laboratory (Hydroisotop $\mathrm{GmbH}$ Lab), the water-sample cylinders were connected to a special cell to measure the $\mathrm{pH}$ without contact with ambient air. Several millilitres of water was immediately used for alkalinity measurements via titration.

Cations $\mathrm{Li}^{+}, \mathrm{Na}^{+}, \mathrm{K}^{+}, \mathrm{Mg}^{2+}, \mathrm{Ca}^{2+}$, and $\mathrm{Sr}^{2+}$ were analysed with a Dionex ion chromatograph using an lonPac CG $12 \mathrm{~A}, 4 \times 50 \mathrm{~mm}$ guard column, and CS $12 \mathrm{~A} 4 \times 250 \mathrm{~mm}$ analytical column. Anions $\mathrm{Cl}^{-}, \mathrm{NO}_{3}{ }^{-}, \mathrm{SO}_{4}{ }^{2-}, \mathrm{Br}^{-}, \mathrm{I}^{-}$, $\mathrm{HPO}_{4}{ }^{2-}, \mathrm{S}_{2} \mathrm{O}_{3}{ }^{2-}$, and acetate were analysed with a Dionex ion chromatograph ICS 1500 using an lonPac AG $224 \times 50 \mathrm{~mm}$ guard column and AS 22, $4 \times 250 \mathrm{~mm}$ analytical column. $\mathrm{NH}^{4+}$ and total sulphide $\left(\mathrm{H}_{2} \mathrm{~S}, \mathrm{~S}^{2-}\right.$, and $\left.\mathrm{HS}_{2}\right)$ were photometrically analysed. $\mathrm{Cr}$, Fe, $\mathrm{Mn}, \mathrm{Co}, \mathrm{Ni}, \mathrm{Cu}, \mathrm{Zn}, \mathrm{As}, \mathrm{Se}, \mathrm{Rb}, \mathrm{Zr}, \mathrm{Nb}$, $\mathrm{Mo}, \mathrm{Cs}$, and $\mathrm{Ba}$ were analysed using inductively coupled plasma mass spectrometry.

Boron is a tracer of glass corrosion because it is a network former released into the solution as early as the start of glass alteration. ${ }^{36,50}$ Furthermore, the alteration products do not retain boron. ${ }^{51}$ The glass corrosion rate, $r\left(\mathrm{~g} \mathrm{~m}^{-2} \mathrm{~d}^{-1}\right)$, is the time derivative of the NL (in $\mathrm{g} \mathrm{m}^{-2}$ ) calculated from the B concentrations. Altered-glass thickness, ET(i), was then calculated from the $\mathrm{NL}(i)$ :

$$
\begin{aligned}
& \mathrm{NL}(i)_{n=1}=\frac{1}{x_{i} S} V_{0}\left(C_{1}-C_{0}\right), \\
& \mathrm{NL}(i)_{n}=\frac{1}{x_{i} S}\left(\left(V_{0}-\sum_{j=1}^{j=n-1} V_{j}\right)\left(C_{j=n}-C_{0}\right)+\sum_{j=1}^{j=n-1} V_{j}\left(C_{j}-C_{0}\right)\right), \\
& \mathrm{ET}(i)=\frac{\mathrm{NL}(i)}{\rho_{g}},
\end{aligned}
$$

where $C_{\mathrm{j}}\left(\mathrm{g} \mathrm{m}^{-3}\right)$ and $V_{\mathrm{j}}$ are the concentration and volume of element $i$ in the solution for the $j$-th sample, respectively, $C_{0}\left(\mathrm{~g} \mathrm{~m}^{-3}\right)$ and $V_{0}\left(\mathrm{~m}^{3}\right)$ are the initial concentration and volume of element $i$ in the initial solution, respectively, $x_{\mathrm{i}}$ is the mass fraction of element $i$ in the glass (g), $S$ is the specific surface area of the glass $\left(\mathrm{m}^{2} \mathrm{~g}^{-1}\right)$ that is in contact with the solution, and $\rho_{\mathrm{g}}$ is the density of the SON68 glass $\left(2.74 \times 10^{6} \mathrm{~g} \mathrm{~m}^{-3}\right)$.

Boron in the solution enabled the estimation of the altered thickness of the glass. The assumption that one mole of $\mathrm{Si}$ in the PRI occupies the same volume as one mole of glass allowed us to estimate the amount of PRI with respect to the altered layer. This hypothesis was also related to the measurement of the diffusion coefficient that was based on this isovolumic assumption. ${ }^{52}$ As shown by small-angle X-ray scattering (SAXS), the collapse of the gel is considered to be limited in a silica saturated medium. ${ }^{53}$ This isovolumetric assumption is extensively discussed in Frugier et al. ${ }^{31}$

\section{Modelling}

The GRAAL model coupled the interdiffusion and dissolution-precipitation reactions following the kinetic law ${ }^{30}$ (Supplementary Information 4). The model assumes that the glass dissolution rate was dependent on diffusion through a dense altered layer formed during saturation. This layer and the gel were described by six end members that were empirically determined. $^{52}$ Its recent implementation in the Phreeq $\mathrm{C}^{54}$ code has enabled diffusive transport in clay by subdividing the pore space into a free uncharged component and a diffuse double layer (DDL) with a surplus of cations that compensated the negative charge of the clay surface. ${ }^{16}$ The model was able to highlight the intricate interactions among diffusive transport, ion exchange, glass dissolution, the amorphous layer, and secondary-phase formation. In addition, multi-component diffusion and anionic exclusion allowed an accurate description of the system's hydrogeology. Thus, the aim of this study was to improve the understanding of the processes that explain glass corrosion in geological media by corroborating the mechanisms highlighted in the laboratory at the field scale using in situ experiments and modelling.

Clay and glass represented two distinct regions in the test interval were the surface is negatively charged. ${ }^{47,55}$ The main process that can explain the negative charge of the glass surface was the dissociation of the silanol groups during hydrolysis, ${ }^{56}$ whereas the substitution $\left(\mathrm{Si}^{4+}\right.$ for $\left.\mathrm{Al}^{3+}\right)$ and charge on the crystal edges (protonation/deprotonation) explained the surface charge of the clay. ${ }^{57,58}$ Based on the low specific surface area of the glass $\left(S_{\text {spec. }}=0.0255 \mathrm{~m}^{2} \mathrm{~g}^{-1}\right)$ as compared with that of the clay $\left(S_{\text {spec. }}=\right.$ $100 \mathrm{~m}^{2} \mathrm{~g}^{-1}$ ), we did not consider the negative contribution of the glass surface in the model. The DDL around the clay represented its negative charge, where the anion concentrations decreased and the cation concentrations increased due to their counter-ion effect. The entire pore space was not accessible to the anions. Thus, the cations were present at higher concentrations in the DDL. The cation distribution between the DDL and porewater depended on the cation exchange capacity (CEC) of the clay. As the diffusion fluxes are related to the concentrations, higher concentration gradients resulted in higher diffusion. Therefore, the diffusion coefficients of the cations, anions, and neutral species in the clay porewater had different values, such that the accessible porosity varied and depended on the charge of the ions. ${ }^{47}$

The Thermochimie v9 database was used. ${ }^{59}$ The diffusion coefficient through the PRI, i.e. $D_{\mathrm{PRI}}$, was taken from Chave et al. ${ }^{60} \mathrm{~A}$ CEC of $0.174 \mathrm{eq} /$ $\mathrm{kg}^{61}$ was included in the form of surface complexation reactions for the half-exchange reactions on surface site $\mathrm{Su}^{-}:^{19}$

$\mathrm{Na}^{+}+\mathrm{Su}^{-} \leftrightarrow \mathrm{NaSu} ; \log \mathrm{K}_{\mathrm{NaSu}}=-0.7$

The cation exchange constant measured on the COx claystone ${ }^{29,61}$ enabled the determination of the surface complexation constant (Table 1). ${ }^{47}$ The surface complexation model allowed charge distribution between the DDL and surface. ${ }^{62}$ The DDL composition was calculated using the Donnan approximation (Eqs. 6 and 7). With these options, solute species could be transported in the coexisting charged and uncharged regions. The COx water content $(\omega)$ was $8 \%,{ }^{29}$ with a dry density $\left(\rho_{\mathrm{dry}}\right)$ of $2.7 \mathrm{~kg} \mathrm{~L}^{-1}$. The anionic exclusion (f) was estimated at 0.5 for the COx. ${ }^{61}$ The mass of rock $(m)$ in each model cell was calculated using Eq. 6:

$m=\rho_{\text {dry }} \times \frac{1-\omega}{\omega}$,

Donnan thickness $=\frac{f \times V}{S_{\text {spec. }} \times m}$,

where $V$ is the volume of water in each cell.

The rock dry density, water content accessible to anions, and specific surface and exchange capacity were translated to a surface for each cell of the model. The surface charge was balanced at each time step by a surplus of counter-ions in the diffuse layer during the calculation.

The 1-D radial model domain was subdivided into cells with an increasing length and extended $0.85 \mathrm{~m}$ into the COx formation. The cell size ranged from $0.00275 \mathrm{~m}$ in the glass area to $0.1 \mathrm{~m}$ in the COx formation 
M. Debure et al.

Table 2. The COx mineralogy and kinetic parameters taken into account to model the experiment. The initial phase concentrations estimated via simulations were obtained from Marty et al. ${ }^{63}$ and adapted to the solid/liquid ratios for the machined COx and field

\begin{tabular}{llcc}
\hline Mineral name & $\begin{array}{l}\text { Initial mineral content in machined } \\
\mathrm{COx}\left(\mathrm{mol} \mathrm{L}^{-1}\right) \text { at } \mathrm{R}_{\mathrm{SL}}=1931 \mathrm{~g} \mathrm{~L}^{-1}\end{array}$ & $\begin{array}{l}\text { Initial mineral content in COx (mol L } \\
\left.\text { at } \mathrm{R}_{\mathrm{SL}}=12,500 \mathrm{~g} \mathrm{~L}^{-1}\right)\end{array}$ & $\begin{array}{l}\text { Reactive surface } \\
\text { area }\left(\mathrm{m}^{2} \mathrm{~g}^{-1}\right)\end{array}$ \\
\hline Calcite & 4.488 & 29.043 & 0.7 \\
Celestite & 0.115 & 0.742 & 40 \\
Dolomite & 0.439 & 2.843 & 0.09 \\
Chlorite-Cca2/Ripidolite-Cca2 & 0.057 & 0.371 & 0.0027 \\
Illite-IMt2 & 1.719 & 11.123 & 30 \\
Pyrite & 0.172 & 1.112 & 0.05 \\
Quartz & 8.135 & 52.648 & 0.012 \\
\hline
\end{tabular}

(Supplementary Fig. 2). Kinetic control was set for the pristine phases (SON68 and COx minerals) and PRI, whereas thermodynamic equilibrium was assumed for the secondary phases (Fe and Mg silicates, goethite, gypsum, etc., see Supplementary Tables 4, 5) and non-passivating gel. The COx kinetic parameters and mineral content were obtained from previous studies and are summarized in Table $2 .^{63}$ The mass of clay was calculated based on the volume of the radial domain and dry density of the clay $\left(2.7 \mathrm{~kg} \mathrm{~L}^{-1}\right)$, which led to a $53.5 \mathrm{~kg}$ mass of machined COx and $868 \mathrm{~kg}$ of field COx in the model. The solid/liquid ratio was then deduced from the COx water content $(8 \%)$ and water injection along the interval, yielding $1931 \mathrm{~kg} \mathrm{~L}^{-1}$ for the machined COx and $12,500 \mathrm{~kg} \mathrm{~L}^{-1}$ for the field COx in the model. The initial solution considered in the reservoir, the internal filter and the glass area is the synthetic porewater while in the rest of the domain (COx core, external filter and $\mathrm{COx}$ formation) the pristine $\mathrm{COx}$ porewater is considered.

\section{DATA AVAILABILITY}

The datasets generated during the current study are available in the Supplementary Information or from the corresponding author upon reasonable request.

Received: 18 April 2019; Accepted: 9 October 2019;

Published online: 31 October 2019

\section{REFERENCES}

1. Staudigel, H. et al. 3.5 billion years of glass bioalteration: volcanic rocks as a basis for microbial life? Earth-Sci. Rev. 89, 156-176 (2008).

2. Staudigel, H. \& Hart, S. R. Alteration of basaltic glass: Mechanisms and significance for the oceanic crust-seawater budget. Geochimica et. Cosmochimica Acta 47, 337-350 (1983).

3. Gysi, A. P. \& Stefánsson, A. $\mathrm{CO}_{2}$-water-basalt interaction. Low temperature experiments and implications for $\mathrm{CO}_{2}$ sequestration into basalts. Geochimica et. Cosmochimica Acta 81, 129-152 (2012).

4. Alloteau, F. et al. New insight into atmospheric alteration of alkali-lime silicate glasses. Corros. Sci. 122, 12-25 (2017).

5. Sessegolo, L. et al. Long-term weathering rate of stained-glass windows using $\mathrm{H}$ and O isotopes. npj Mater. Degrad. 2, 17 (2018).

6. Hellmann, R. et al. Nanometre-scale evidence for interfacial dissolutionreprecipitation control of silicate glass corrosion. Nat. Mater. 14, 307 (2015).

7. Cailleteau, C. et al. Insight into silicate-glass corrosion mechanisms. Nat. Mater. 7, 978-983 (2008).

8. Poinssot, C., Fillet, C. \& Gras, J. M. in Geological Repository Systems for Safe Disposal of Spent Nuclear Fuels and Radioactive Waste (eds Ahn, J. \& Apted, M. J.) 421-493 (Woodhead Publishing, 2010).

9. Gin, S., Jollivet, P., Fournier, M., Angeli, F., Frugier, P. \& Charpentier, T. Origin and consequences of silicate glass passivation by surface layers. Nat. Commun. $\mathbf{6}$, 6360-6367, https://doi.org/10.1038/ncomms7360 (2015).

10. Bildstein, O. \& Claret, F. in Developments in Clay Science Vol. 6 (eds Tournassat, C. et al.) 155-188 (Elsevier, 2015).

11. Debure, M., De Windt, L., Frugier, P. \& Gin, S. HLW glass dissolution in the presence of magnesium carbonate: Diffusion cell experiment and coupled modeling of diffusion and geochemical interactions. J. Nucl. Mater. 443, 507-521 (2013).
12. Debure, M., Frugier, P., De Windt, L. \& Gin, S. Dolomite effect on borosilicate glass alteration. Appl. Geochem. 33, 237-251 (2013).

13. Burger, E. et al. Impact of iron on nuclear glass alteration in geological repository conditions: a multiscale approach. Appl. Geochem. 31, 159-170 (2013).

14. Schlegel, M. L. et al. Alteration of nuclear glass in contact with iron and claystone at $90^{\circ} \mathrm{C}$ under anoxic conditions: characterization of the alteration products after two years of interaction. Appl. Geochem. 70, 27-42 (2016).

15. Jollivet, P. et al. Effect of clayey groundwater on the dissolution rate of the simulated nuclear waste glass SON68. J. Nucl. Mater. 420, 508-518 (2012).

16. Debure, M., De Windt, L., Frugier, P. \& Gin, S. Mechanisms involved in the increase of borosilicate glass alteration by interaction with the Callovian-Oxfordian clayey fraction. Appl. Geochem. 98, 206-220 (2018).

17. Fournier, M., Frugier, P. \& Gin, S. Application of GRAAL model to the resumption of International Simple Glass alteration. npj Mater. Degrad. 2, 21 (2018).

18. Maher, K., Steefel, C. I., DePaolo, D. J. \& Viani, B. E. The mineral dissolution rate conundrum: insights from reactive transport modeling of $U$ isotopes and pore fluid chemistry in marine sediments. Geochimica et. Cosmochimica Acta 70, 337-363 (2006).

19. Appelo, C. A. J., Vinsot, A., Mettler, S. \& Wechner, S. Obtaining the porewater composition of a clay rock by modeling the in- and out-diffusion of anions and cations from an in-situ experiment. J. Contaminant Hydrol. 101, 67-76 (2008).

20. Debure, M., De Windt, L., Frugier, P., Gin, S. \& Vieillard, P. Mineralogy and thermodynamic properties of magnesium phyllosilicates formed during the alteration of a simplified nuclear glass. J. Nucl. Mater. 475, 255-265 (2016).

21. Aréna, $\mathrm{H}$. et al. Impact of iron and magnesium on glass alteration: Characterization of the secondary phases and determination of their solubility constants. Appl. Geochem. 82, 119-133 (2017).

22. Curti, E., Crovisier, J. L., Morvan, G. \& Karpoff, A. M. Long-term corrosion of two nuclear waste reference glasses (MW and SON68): a kinetic and mineral alteration study. Appl. Geochem. 21, 1152-1168 (2006).

23. Dillmann, P., Gin, S., Neff, D., Gentaz, L. \& Rebiscoul, D. Effect of natural and synthetic iron corrosion products on silicate glass alteration processes. Geochimica et. Cosmochimica Acta 172, 287-305 (2016).

24. Mercado-Depierre, S., Angeli, F., Frizon, F. \& Gin, S. Antagonist effects of calcium on borosilicate glass alteration. J. Nucl. Mater. 441, 402-410 (2013).

25. Thien, B. M., Godon, N., Ballestero, A., Gin, S. \& Ayral, A. The dual effect of Mg on the long-term alteration rate of AVM nuclear waste glasses. J. Nucl. Mater. 427, 297-310 (2012).

26. Neeway, J., Abdelouas, A., Grambow, B. \& Schumacher, S. Dissolution mechanism of the SON68 reference nuclear waste glass: new data in dynamic system in silica saturation conditions. J. Nucl. Mater. 415, 31-37 (2011).

27. Neeway, J. et al. Effect of Callovo-Oxfordian clay rock on the dissolution rate of the SON68 simulated nuclear waste glass. J. Nucl. Mater. 459, 291-300 (2015).

28. Gin, S. et al. An international initiative on long-term behavior of high-level nuclear waste glass. Mater. Today 16, 243-248 (2013).

29. Gaucher, E. et al. ANDRA underground research laboratory: interpretation of the mineralogical and geochemical data acquired in the Callovian-Oxfordian formation by investigative drilling. Phys. Chem. Earth, Parts A/B/C. 29, 55-77 (2004).

30. Frugier, $P$. et al. SON68 nuclear glass dissolution kinetics: Current state of knowledge and basis of the new GRAAL model. J. Nucl. Mater. 380, 8-21 (2008).

31. Frugier, P., Minet, Y., Rajmohan, N., Godon, N. \& Gin, S. Modeling glass corrosion with GRAAL. npj Mater. Degrad. 2, 35 (2018).

32. Tournassat, C., Gaucher, E. C., Fattahi, M. \& Grambow, B. On the mobility and potential retention of iodine in the Callovian-Oxfordian formation. Phys. Chem. Earth, Parts A/B/C. 32, 539-551 (2007). 
33. Vinsot, A., Linard, Y., Lundy, M., Necib, S. \& Wechner, S. Insights on Desaturation Processes based on the Chemistry of Seepage Water from Boreholes in the Callovo-Oxfordian Argillaceous Rock. Procedia Earth Planet. Sci. 7, 871-874 (2013).

34. Pozo, C., Bildstein, O., Raynal, J., Jullien, M. \& Valcke, E. Behaviour of silicon released during alteration of nuclear waste glass in compacted clay. Appl. clay Sci. 35, 258-267 (2007)

35. Suzuki-Muresan, T., Vandenborre, J., Abdelouas, A. \& Grambow, B. Solution controls for dissolved silica at 25,50 and $90^{\circ} \mathrm{C}$ for quartz, Callovo-Oxfordian claystone, illite and MX80 bentonite. Phys. Chem. Earth, Parts A/B/C. 36, 1648-1660 (2011).

36. Gin, S., Beaudoux, X., Angéli, F., Jégou, C. \& Godon, N. Effect of composition on the short-term and long-term dissolution rates of ten borosilicate glasses of increasing complexity from 3 to 30 oxides. J. Non-Crystalline Solids $\mathbf{3 5 8}$, 2559-2570 (2012).

37. Bouakkaz, R., Abdelouas, A., El Mendili, Y., Grambow, B. \& Gin, S. SON68 glass alteration under Si-rich solutions at low temperature $\left(35-90^{\circ} \mathrm{C}\right)$ : kinetics, secondary phases and isotopic exchange studies. RSC Adv. 6, 72616-72633 (2016).

38. Jollivet, P., Gin, S. \& Schumacher, S. Forward dissolution rate of silicate glasses of nuclear interest in clay-equilibrated groundwater. Chem. Geol. 330, 207-217 (2012).

39. Gin, S. et al. The controversial role of inter-diffusion in glass alteration. Chem. Geol. 440, 115-123 (2016).

40. Michelin, A. et al. Archeological slag from Glinet: an example of silicate glass altered in an anoxic iron-rich environment. Chem. Geol. 413, 28-43 (2015).

41. Hemming, N. G., Reeder, R. J. \& Hart, S. R. Growth-step-selective incorporation of boron on the calcite surface. Geochimica et. Cosmochimica Acta 62, 2915-2922 (1998).

42. Mavromatis, V., Montouillout, V., Noireaux, J., Gaillardet, J. \& Schott, J. Characterization of boron incorporation and speciation in calcite and aragonite from co-precipitation experiments under controlled $\mathrm{pH}$, temperature and precipitation rate. Geochimica et. Cosmochimica Acta 150, 299-313 (2015).

43. Debure, M. et al. Retention of arsenic, chromium and boron on an outcropping clay-rich rock formation (the Tégulines Clay, eastern France). Sci. Total Environ. 642, 216-229 (2018).

44. Couch, E. L. \& Grim, R. E. Boron fixation by illites. Clays Clay Miner. 16(3), 249-256 (1968).

45. Fleet, M. Preliminary investigations into the sorption of boron by clay minerals. Clay Min. 6, 3-16 (1965).

46. Goldberg, S. Reactions of boron with soils. Plant Soil 193, 35-48 (1997).

47. Appelo, C. in Water Pollution in Natural Porous Media at Different Scales. Assessment of Fate, Impact and Indicators. WAPO (eds Candela, L. et al.) 3-13 (Instituto Geologico y Minero de Espana, 2007).

48. Gaucher, E. C. et al. A robust model for pore-water chemistry of clayrock. Geochimica et. Cosmochimica Acta 73, 6470-6487 (2009).

49. Brunauer, S., Emmett, P. H. \& Teller, E. Adsorption of gases in multimolecular layers. J. Am. Chem. Soc. 60, 309-319 (1938).

50. Doremus, R. H. in Glass Surfaces (ed Day, D. E.) 137-144 (Elsevier, 1975).

51. Scheetz, B., Freeborn, W., Smith, D., Anderson, C., Zolensky, M. \& White, W. The role of boron in monitoring the leaching of borosilicate glass waste forms. MRS Proc. 44, 129, https://doi.org/10.1557/PROC-44-129 (1984).

52. Rajmohan, N., Frugier, P. \& Gin, S. Composition effects on synthetic glass alteration mechanisms: Part 1. Experiments. Chem. Geol. 279, 106-119 (2010).

53. Spalla, O., Barboux, P., Sicard, L., Lyonnard, S. \& Bley, F. Influence of insoluble elements on the nanostructure of water altered glasses. J. non-crystalline solids 347, 56-68 (2004).

54. Parkhurst, D. L. \& Appelo, C. A. J. Description of Input and Examples for PHREEQC Version 3-a Computer Program for Speciation, Batch-reaction, One-dimensional Transport, and Inverse Geochemical Calculations. U.S. Geological Survey Techniques and Methods, book 6, chap. A43 edn, p. 497 (2013).

55. Behrens, S. H. \& Grier, D. G. The charge of glass and silica surfaces. J. Chem. Phys. 115, 6716-6721 (2001)

56. Iler, R. K. The chemistry of silica: solubility, polymerization, colloid and surface properties, and biochemistry of Silica. p. 896 (Wiley, 1979).

57. Sposito, G. et al. Surface geochemistry of the clay minerals. Proc. Natl. Acad. Sci. 96, 3358-3364 (1999).
58. Zhou, Z. \& Gunter, W. D. The nature of the surface charge of kaolinite. Clays Clay Miner. 40, 365-368 (1992).

59. Giffaut, E. et al. Andra thermodynamic database for performance assessment: ThermoChimie. Appl. Geochem. 49, 225-236 (2014).

60. Chave, T., Frugier, P., Ayral, A. \& Gin, S. Solid state diffusion during nuclear glass residual alteration in solution. J. Nucl. Mater. 362, 466-473 (2007).

61. Gaucher, É. C. et al. Modelling the porewater chemistry of the Callovian-Oxfordian formation at a regional scale. Comptes Rendus Geosci. 338, 917-930 (2006).

62. Dzombak, D. A. \& Hudson, R. J. Ion exchange: the contributions of diffuse layer sorption and surface complexation. Adv. Chem. Ser. 244, 59-59 (1995).

63. Marty, N. C. M. et al. A database of dissolution and precipitation rates for clayrocks minerals. Appl. Geochem. 55, 108-118 (2015).

\section{ACKNOWLEDGEMENTS}

This research was financially supported by the BRGM-Andra scientific partnership (MLH/MVE project). We would like to thank Editage (www.editage.com) for English language editing. We warmly acknowledge Christophe Chiaberge (BGRM) for its help with mathematics and Christophe Tournassat (BRGM) for the discussions on DDL.

\section{AUTHOR CONTRIBUTIONS}

M.D. made the calculations and wrote an early version of the manuscript. Y.L. was in charge of the experiment in the Meuse/Haute-Marne Underground Research Laboratory. Y.L. and C.M. were in charge of the R\&D studies that dealt with the long-term behaviour of radioactive vitrified waste under disposal conditions for the Cigéo deep geological disposal project. M.D. and F.C. conceptualised the modelling. All authors contributed to the writing of the manuscript.

\section{COMPETING INTERESTS}

The authors declare no competing interests.

\section{ADDITIONAL INFORMATION}

Supplementary information is available for this paper at https://doi.org/10.1038/ s41529-019-0100-7.

Correspondence and requests for materials should be addressed to M.D.

Reprints and permission information is available at http://www.nature.com/ reprints

Publisher's note Springer Nature remains neutral with regard to jurisdictional claims in published maps and institutional affiliations.

\begin{abstract}
Open Access This article is licensed under a Creative Common Attribution 4.0 International License, which permits use, sharing, adaptation, distribution and reproduction in any medium or format, as long as you give appropriate credit to the original author(s) and the source, provide a link to the Creative Commons license, and indicate if changes were made. The images or other third party material in this article are included in the article's Creative Commons license, unless indicated otherwise in a credit line to the material. If material is not included in the article's Creative Commons license and your intended use is not permitted by statutory regulation or exceeds the permitted use, you will need to obtain permission directly from the copyright holder. To view a copy of this license, visit http://creativecommons. org/licenses/by/4.0/
\end{abstract}

(C) The Author(s) 2019 